Article

\title{
Towards Evaluation of Environmental Spatial Order of Natural Valuable Landscapes in Suburban Areas: Evidence from Poland
}

\author{
Renata Różycka-Czas* $*$, Barbara Czesak $@$ and Katarzyna Cegielska \\ Department of Spatial Management and Landscape Architecture, Faculty of Environmental Engineering and \\ Land Surveying, University of Agriculture in Krakow, Balicka 253 c, 30-198 Kraków, Poland; \\ barbara.czesak@urk.edu.pl (B.C.); k.cegielska@urk.edu.pl (K.C.) \\ * Correspondence: renata.rozycka-czas@urk.edu.pl
}

Received: 30 September 2019; Accepted: 18 November 2019; Published: 20 November 2019

\begin{abstract}
The aim of the paper is to develop a method to evaluate and monitor environmental spatial order to delimit problem areas. The method was tested on the carefully chosen suburban areas as natural valuable areas located in suburban and peri-urban areas are particularly prone to intense and chaotic development. The number of methods of spatial order evaluation is scarce. The paper is an attempt to fill this gap. We have used following indicators: afforestation rate, landscape diversity level, density of the total road network, rate of compact development, as well as the building intensity. Indicators used in the method have been chosen based on the literature and modified to adjust it to the available data. Our findings confirm that the method gives reliable results. It can be used to evaluate the efficacy of Local Spatial Development Plans and Environmental Protection Plans. Moreover, we delimited areas in which environmental spatial order could be improved.
\end{abstract}

Keywords: spatial order; spatial planning; natural valuable areas; cultural landscape; protected areas

\section{Introduction}

Human population growth accompanied by the decrease in natural areas and their fragmentation are the main challenges for planners, landscape ecologists and conservation biologists $[1,2]$. Rapid urbanization is associated with radical transformation of land use, disorder in landscape layout, and fragile ecological environment [3]. As noted by Zang [4] during the process of land conversion, economic development and improvement of quality of life are considered to be major goals, but their influence on ecological systems have often been neglected. The same problem relates to landscape and cultural heritage. Natural and rural landscapes have not always been considered in the lexicon of urban and regional planning and they are often relegated and treated as "inessential" [5]. At the same time, appropriate accessibility to natural valuable areas and balance between natural and urban forms of land use and land cover is crucial for well-being of city inhabitants who are a growing part of the world's population [6].

This balance is particularly hard to maintain in suburban areas, where the main type of development is sprawl. According to Moroni and Minola [7], focus on sprawl development (urban sprawl) has slightly shifted from the U.S. to Europe, where it is a relatively new phenomenon and where it causes land-use conflicts and threatens sustainable land use [8]. Despite many European efforts, metropolisation and urban sprawl processes are still active and do not slowdown in Europe [9]. The situation is the same in Poland, where suburbanization leading to sprawl development [10] is the dominant process in metropolitan areas [11]. Due to quick and exuberant building process and the progressive anthropogenic transformations of natural landscape [12] smart development planning 
becomes particularly important for suburbs. This need is highlighted in the recommendation of "The New Charter of Athens 2003-The European Council of Town Planners' Vision for Cities in the 21st Century" [13] which points out that in the connected city "the natural areas of the Continent will be effectively protected against the extension and multiplication of these urban networks, through a combination of regulatory and stimulatory measures, as well as by promoting awareness of their value and the essential need for conservation and enhancement". Discussions on the sustainability of both the natural and built environment frequently arise not only among urban designers and planners but also in public awareness. Nowadays, cities and their inhabitants expect an increase of well-being and better quality of life which harmoniously combine the urban environment with the natural environment.

Attaining this goal is extremely hard when the spatial planning system is weak [14-16] and suburbanization process is as active as in Poland $[17,18]$. The most important spatial consequence of suburbanization is degradation of the valuable open spaces crucial for sustainable development [19]. The conversion of land from natural areas or agricultural production to urban and industrial development is one of the most significant processes in Polish spatial planning in recent years [20,21]. As Barnes et al. [22] suggested, urban land uses are viewed as interrupting and fragmenting previously homogenous rural landscapes, thereby increasing landscape disorganization. According to Kepkowicz et al. [23], landscape is inharmonious in most suburban areas in Poland. Several authors point out the ugliness of suburban landscape [24,25], the loss of its scenic value and degradation of natural landscape [26]. Environmental degradation is a problem not only for suburban areas but it continues to be a major problem inside the cities as the open space available per capita is decreasing [27]. At the same time spatial continuity of natural areas and access for residents are the main challenges of city management and spatial planning.

The main legal act regulating Polish spatial planning is the Act of 23 March 2003 on Spatial Planning and Development [28]. This act defines the forms of use for particular areas as well as outlines development principles for these areas. According to the act, all types of activities associated with spatial policy and land use management at all levels of spatial planning system should be based on spatial order and sustainable development.

While sustainable development is well defined and known worldwide, spatial order is a term specific to Poland. The term is related to sustainable development as well as landscape protection. Kołodziejski [29] claims that sustainable development shaping is strongly linked to spatial order shaping. Kozłowski [30] pointed out that a harmonious landscape can be a sign of spatial order. However, lack of spatial order is common in Poland. National Spatial Development Concept 2030 [31] notes following indicators of lack of spatial order at the local level in Poland, i.e., chaos in the forms of building and urban complexes, rapid urban expansion in open areas, as well as shortcomings in social and technical infrastructure.

In this paper, we assume that creating spatial order is crucial for maintaining natural and urban balance. However, there is great uncertainty in defining exactly what spatial order is and what is the best method of its evaluation. The major objective of this study was to develop a method to measure and monitor environmental spatial order, which can be used by municipal authorities. The detailed aims of the research were: 1) to determine if any natural valuable areas covered main Polish Functional Urban Areas, 2) to determine suburban areas characterized by quick housing development as well as high percentage of natural valuable areas in total area, 3) to evaluate spatial order of natural valuable areas in test fields, 4) to arrange test fields (hexagons) according to a hierarchy, 5) to check if any differences between the condition of spatial order in National Parks and Landscape Parks are noticeable, and 6) to highlight the needs for monitoring and protection of natural valuable areas located in suburbs.

\section{Spatial Order in Spatial Planning System}

According to the Act [28], "spatial order is spatial development that creates a harmonious whole and includes-in well-ordered relations-all the conditions and demands: functional, socio-economic, environmental, cultural, as well as compositional and aesthetic". However, even though the Act gives 
a definition of spatial order, this definition is inaccurate [32-36] and it does not give any technical guidelines which could be helpful for spatial order evaluation. To solve this issue, many researchers have proposed their own spatial order definitions, as well as various methods of its evaluation.

According to Balon [37] "spatial orders are meant to represent main regularities in the "ordering" of the natural environment in space, i.e., its spatial diversification considered in a holistic way". Szolginia [38] claimed that spatial order can be defined as that kind of a spatial organization that could be generated twofold: in a natural way, as a result of the forces of nature and in an artificial way, by human activity. In this paper we use the definition by Markowski [39]: order is a human subjective feeling of harmony built by the elements of widely understood man's surroundings. The ability to distinguish order from disharmony (a mess, chaos) is an innate ability of all humans. However, this does not mean that man or society has an innate and universal ability to maintain order.

Many researchers point out that spatial order is a hard to measure, interdisciplinary, and multipronged phenomenon [35,40-44]. It consists of several aspects, and each may be described by various variables. The main difficulty in evaluating spatial order is the selection of its variables [45], and of appropriate indicators which describe all dimensions of this complex phenomenon. Accordingly, researchers often selected a particular aspect of spatial order i.e., environmental [46], socio-economic [47], cultural, functional [43,48], or aesthetic to define and measure it. Frequently, researchers refer to nature while defining spatial order. Parysek [49] claimed that nature itself can be treated as a synonym for the natural order because the undisturbed nature regulates itself and functions well. So, in the spatial context we should remember that the basic, primary element of any given area is nature. Moreover this aspect of spatial order is the most difficult to maintain unchanged, and always hard to restore [46].

For the evaluation of the spatial order multidimensional comparative analysis [36,45] as well as the point, the assessment method is widely used (see [50-52]). Galiński et al., [53] describe point assessment method as a tool for the valorization of spatial phenomena. Even though such approach is burdened with a number of simplifications, it is impossible to evaluate spatial order holistically and use all necessary indicators.

Even if strategic spatial planning is conducted at the national and provincial level, municipalities are the key player in the Polish planning system, and they have considerable market power within their own jurisdiction. The main role of local spatial planning is to create spatial order, which is the primary challenge of shaping the investment process. In Polish spatial planning and environmental protection systems there are few main tools to provide balance between natural and urban areas. The most important are Local Spatial Development Plan (LSDP) and environmental protection plan (EPPs). LSDPs may be created for whole municipality or just for their parts, neighboring municipalities cannot share the same spatial plane. Moreover, LSDPs are optional documents and only about $30 \%$ of Polish territory is covered by them [54]. Such selective spatial planning usually does not cover areas with restrictive protective measures. Those areas are vulnerable to rapid development, especially when the areas are in private hands [55]. LSDPs in rural areas are crucial for the protection of nature and landscape [56]. Local authorities should use them to shape spatial policy by allocating areas for specific purposes and determining the principles of their development. Such actions put together with sustainable development should strengthen and consolidate spatial order [57], which is the legal responsibility of each municipality [28]. At the same time EPPs are obligatory documents created for National Parks, Landscape Protection Parks and Reserves [58], which main role is protection and conservation of natural valuable areas, as well as providing principles of land use and development in these areas. However, it is difficult to create and maintain spatial order without clear, technical definition and rules of spatial order evaluation. Evaluation of spatial order is particularly vulnerable to subjective opinions, so it is crucial to determine the substantive rules of the evaluating process and strive for its automation to adjust it to municipalities needs. Such fitting spatial order evaluation method would improve strategic and planning documents quality. 
As spatial order is a very broad concept [59], we evaluated only the environmental aspect. We assumed that the environmental spatial order is created by the balance between natural and urban elements. In this paper spatial order of natural areas is defined as diversification of the elements and features of the land use.

\section{Research Area}

In more than 75\% of Polish cities, the population of the city core declined in 2019 [60] and the number of inhabitants of the suburban area increased. The size of the population of the urban center affects the intensity of the suburbanization process. The bigger is the city the more intensive is the strength of the suburbanization process. Therefore, we have chosen the ten most populated cities and their FUAs as initial research areas. Functional Urban Areas (FUAs) of the cities have been determined according EU-OECD definition [61]. First the suburban municipalities with the most rapid development have been selected (Figure 1).

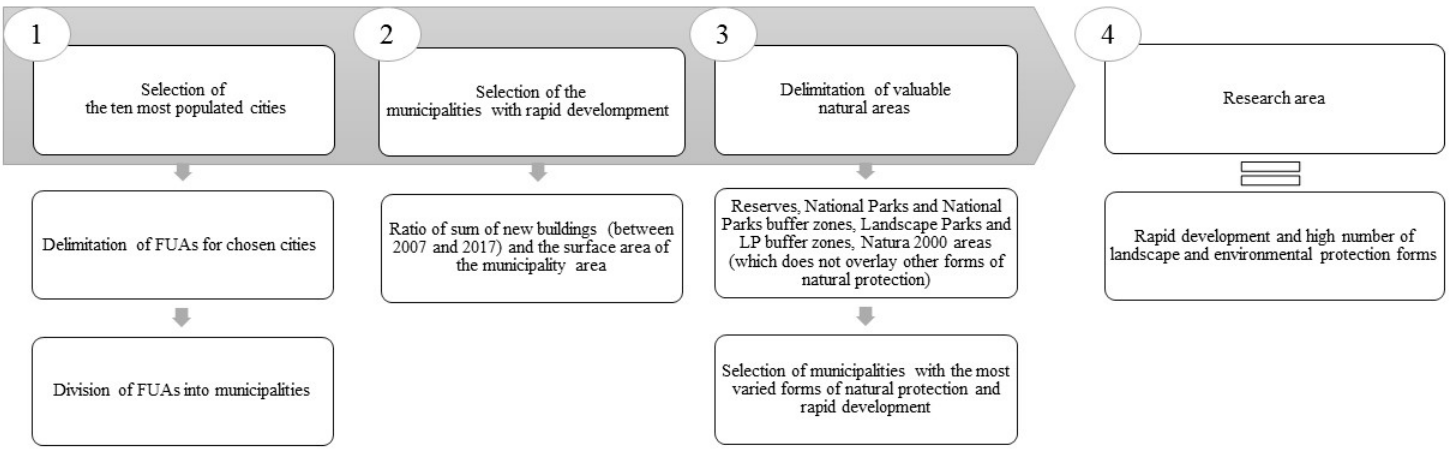

Figure 1. Selection of research area.

Rapid development was calculated as the ratio of the sum of new buildings (between 2007 and 2017) and the surface area of the municipality. The next step was to determine what is the quantity and quality of natural valuable areas in the selected municipalities. Table 1 shows that the most rapid development occurs around Warsaw in Kobyłka and Marki, but the cover of the natural valuable area in both communities is under $5 \%$.

Legionowo and Zabki municipalities also grow rapidly but they do not have any forms of nature protection. Two other municipalities with the rapid development that were considered are Łomianki and Zielonki. Both municipalities are characterized by similar rapid development and covered with natural valuable areas almost entirely. Łomianki is covered with National Park and its buffer protection zone. In Zielonki there are seven various Landscape Parks and their buffer zones, and buffer zone of a National Park. The main objective of National Parks is protection of the nature and its landscape values and restoration of habitats [58]. Therefore, we have chosen Zielonki as the aim of the paper is to explore spatial order of protected landscapes and Zielonki has bigger variety of landscape protection forms. Zielonki municipality belongs to the Krakow agglomeration (Figure 2) which spreads over four thousand square kilometers. It is located in the first ring of municipalities which consists of 12 communes directly adjacent to Krakow. 
Table 1. Test area selection: natural protection and rapid development.

\begin{tabular}{|c|c|c|c|c|}
\hline FUA & Municipality & $\begin{array}{l}\text { Ratio of Sum of New } \\
\text { Buildings (from } 2007 \text { to } \\
\text { 2017) to Total Area in km² }\end{array}$ & $\begin{array}{l}\text { Form of Natural } \\
\text { Protection }\end{array}$ & $\begin{array}{c}\text { Number of } \\
\text { Different } \\
\text { Protection Forms }\end{array}$ \\
\hline \multirow[t]{12}{*}{ Warszawa } & Kobyłka & 102 & $\begin{array}{c}\mathrm{R}(<5 \% \text { of } \\
\text { municipality area })\end{array}$ & 1 \\
\hline & Marki & 101 & $\begin{array}{c}\mathrm{R}(<5 \% \text { of } \\
\text { municipality area) }\end{array}$ & 1 \\
\hline & Legionowo & 95 & - & 0 \\
\hline & Ząbki & 93 & - & 0 \\
\hline & Łomianki & 62 & $\begin{array}{l}\mathrm{NP} / \mathrm{NPbz}(100 \% \text { of } \\
\text { municipality area) }\end{array}$ & 2 \\
\hline & Piastów & 57 & - & 0 \\
\hline & Pruszków & 49 & - & 0 \\
\hline & Lesznowola & 47 & - & 0 \\
\hline & Milanówek & 46 & - & 0 \\
\hline & Sulejowek & 45 & - & 0 \\
\hline & Mińsk Mazowiecki & 45 & - & 0 \\
\hline & Józefów & 40 & $\mathrm{R} / \mathrm{LP} / \mathrm{LPbz}$ & 3 \\
\hline Kraków & Zielonki & 50 & $\begin{array}{c}\mathrm{NPbz} / \mathrm{LP} / \mathrm{LPbz}(7 \\
\text { different LPs) }\end{array}$ & 3 \\
\hline Łódź & & $<40$ & - & 0 \\
\hline Wrocław & & $<40$ & - & 0 \\
\hline \multirow[t]{2}{*}{ Poznań } & Luboń & 87 & - & 0 \\
\hline & Komorniki & 60 & $\mathrm{NP} / \mathrm{NPbz}$ & 2 \\
\hline \multirow[t]{2}{*}{$\begin{array}{l}\text { Tri-City (Gdańsk, } \\
\text { Gdynia, Sopot) }\end{array}$} & Rumia & 45 & LP & 1 \\
\hline & Pruszcz Gdański & 45 & - & 0 \\
\hline Szczecin & & $<40$ & - & 0 \\
\hline Bydgoszcz & & $<40$ & - & 0 \\
\hline Lublin & Lubartów & 57 & - & 0 \\
\hline Białystok & & $<40$ & - & 0 \\
\hline
\end{tabular}

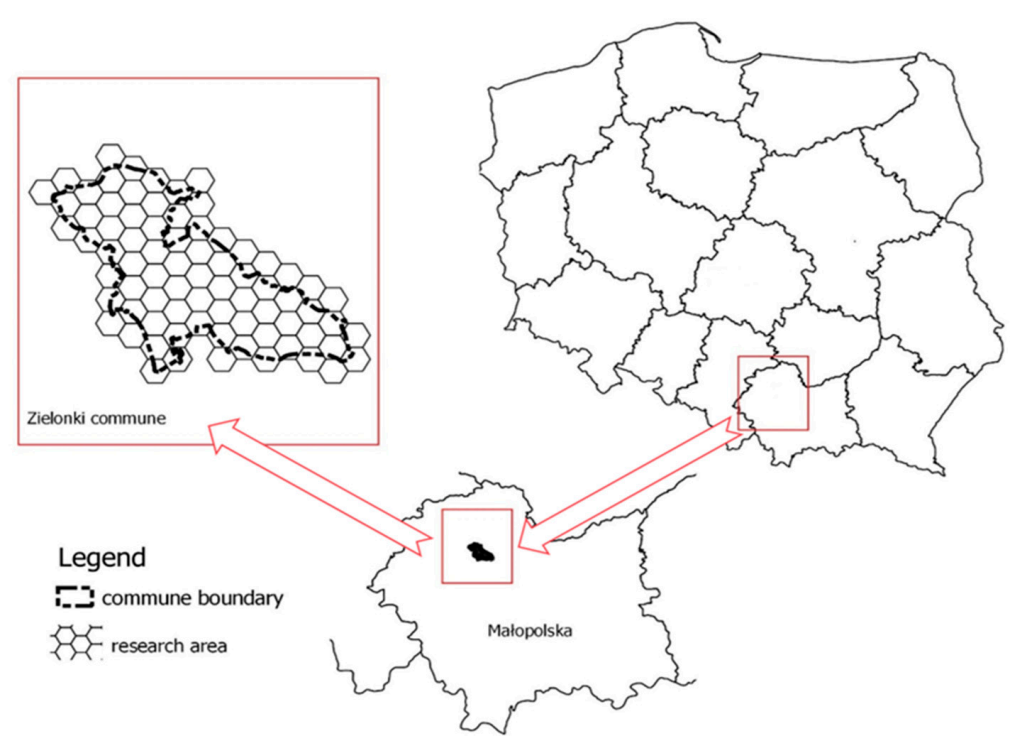

Figure 2. Location of the research area and test fields. 


\section{Materials and Method}

Evaluation of spatial order was carried out with the point assessment method, in which the value of the phenomenon is averaged in the test field. Researchers [62,63] distinguish natural and artificial test fields in the point assessment method. In this paper, we propose artificial fields. To ensure comparability of presented phenomenon regular, $1 \mathrm{~km}$ in size hexagons grid was used. The analysis was conducted on 77 hexagons in the administrative borders of the municipality (Figure 2).

The essential step of the research was to determine the criteria for the classification of the evaluated components and their valorization (Table 2). We have attempted to create the method that will be easily available for the municipalities and is not going to generate extra costs. Therefore, we based our method on available topographic data from BDOT10k, a vector database containing spatial location of topographic objects along with their characteristics. BDOT10k offers few main types of data: water bodies, transport, utilities, land cover, protected area, administrative division, buildings and developed areas [64]. We have analyzed the database and chosen data categories related to environmental spatial order. The first chosen factor was afforestation.

Table 2. Spatial order of natural valuable suburban areas - indicators and points.

\begin{tabular}{ccccc}
\hline \multirow{2}{*}{ Indicator } & \multicolumn{4}{c}{ Points } \\
\cline { 2 - 5 } & $\mathbf{3}$ & $\mathbf{2}$ & $\mathbf{1}$ & $\mathbf{0}$ \\
\hline afforestation rates & above $30 \%$ & $29-20 \%$ & $19-10 \%$ & below $10 \%$ \\
\hline landscape diversity & $\begin{array}{c}\text { 8 or more different } \\
\text { land use classes }\end{array}$ & $\begin{array}{c}7-6 \text { different land } \\
\text { use classes }\end{array}$ & $\begin{array}{c}5-4 \text { different land } \\
\text { use classes }\end{array}$ & $\begin{array}{c}3 \text { or less different } \\
\text { land use classes }\end{array}$ \\
\hline $\begin{array}{c}\text { density of the total road network } \\
\text { (km road/ km }{ }^{2} \text { land area) }\end{array}$ & $\mathrm{q}<=\mathrm{q}_{\mathrm{a}}-0.5 \mathrm{~s}$ & $\mathrm{q}_{\mathrm{a}}+0.5 \mathrm{~s}>\mathrm{q}>\mathrm{q}_{\mathrm{a}}$ & $\mathrm{q} \geq \mathrm{q}_{\mathrm{a}}+0.5 \mathrm{~s}$ & - \\
\hline compact development & below $30 \%$ & $39-30 \%$ & $40-59 \%$ & min. $60 \%$ \\
\hline building intensity & $\mathrm{b}<=\mathrm{b}_{\mathrm{a}}-0.5 \mathrm{~s}$ & $\mathrm{~b}_{\mathrm{a}}+0.5 \mathrm{~s}>\mathrm{b}>\mathrm{b}_{\mathrm{a}}$ & $\mathrm{b} \geq \mathrm{b}_{\mathrm{a}}+0.5 \mathrm{~s}$ & \\
\hline
\end{tabular}

$\mathrm{q}$ - density of the total road network in particular hexagon; $\mathrm{q}_{\mathrm{a}}$-average density of the total road network in entire test fields (hexagons); $s$ - standard deviation; $b$ - building intensity in particular hexagon; $b_{a}$ —average building intensity in entire test fields (hexagons).

Forest cover helps to reduce air and soil pollution, balances water conditions, as well as maintains the biological potential of various species. Especially in the suburbs green open areas play are significant for health protection $[65,66]$ and at the same time they are an important aesthetic element. In this paper afforestation rate, defined as share of forest area in a test field (hexagon) surface area was used. The maximal score was assigned to the areas with over $30 \%$ forest cover. Poland's afforestation rate in 2018 was $29,6 \%$, and an aim for 2050 is $33 \%$ of the surface area of country [67].

The heterogeneity of land cover and the presence of linear features such as hedges, lines of trees, roads, railways, rivers, and irrigation channels are two important elements characterizing landscape structures [68]. Moreover, as Sallay et al. [69] pointed out land use is one of the most dominant scenic elements in the landscape. In this paper the simplified approach was chosen. Landscape diversity level was defined as a number of land cover classes. The following classes were distinguished on the basis of BDOT10k and Corine Land Cover data: arable land, built-up area, roads, industrial and commercial areas, plantations and allotment, arboreous areas and shrubs, wasteland, meadows and pastures, forests, water area.

Valuable natural areas and undeveloped areas become more attractive for residents if there is adequate investment in infrastructure. Such investment may involve the construction of roads and forest tracks, equipping the area with benches or bins, as well as lanterns and keeping green areas clean. That kind of actions make open areas more accessible for residents and enhance their attractiveness [70]. The density of the total road network is the ratio of the length of the text field's total road network to the test field surface area. The road network includes all roads; urban and rural. 
Another indicator is the percentage of the area belonging to compact development in total area. Compact development is defined in the Act on the Protection of Arable and Forest Land [71]. According to the Act compact development is a group of at least 5 buildings (outbuildings are not included), where the longest distance between neighboring buildings must not exceed $100 \mathrm{~m}$. In this paper all types of buildings were included. The area with compact development was calculated as an area of buffer ( $50 \mathrm{~m}$ from the building's centroid) zone. The high percentage of compact development in a test field means that the area is highly urbanized. It might mean that the natural valuable area is inadequately protected from the suburbanization process, and that spatial planning documents (i.e., EPPs, LSDPs) are ineffective.

Building intensity was calculated as an aggregated area of ground floor footprint of building multiplied by the number of floors divided by the hexagon's area. Classic suburbs are areas where the residential function prevails; they usually show a low intensity of building development and a high share of open spaces [72].

We assumed that the data used to describe the condition of spatial order should meet the following criteria: comparability of data, reliability of data, as well as equal availability of data for all hexagons, and moreover for entire FUAs. For that reason, the research was based on data from Topographic GeoDatabase on a nominal scale of 1: 10000 (abbreviation: BDOT10k) obtained from Polish Cadastral Office. The BDOT10k cover classes were generalized because they were too detailed. New classes were created based on Corine Land Cover (CLC) classification. The reclassification process allowed to define 10 new land cover classes created by combining the BDOT10k classes with CLC classes. This resulted in the data with enough accuracy and appropriate scale for our purposes, which could not be provided from the data from CLC inventory only.

Next, geoprocessing methods and spatial relationships in GIS were used. For each test field the appropriate amount of points for all indicators, as well as total number of evaluation points were calculated. The results allowed for ranking the hexagons and grouping them according to the condition of spatial order of natural valuable areas. The Jenks natural breaks classification method was used. The aim of this method is to reduce the variance within classes and maximize the variance between classes [73]. The results of the analyses are presented both in multi-layered compositions and cartograms. Analyses were performed using QGIS 2.18.3. and QGIS 3.4.

\section{Results}

According to Regional Spatial Plan [74], Zielonki municipality belongs to an area with high nature values. The area requires pro-ecological actions as well as counteracting environmental degradation. The entire studied municipality is covered by effective Local Spatial Development Plan (LSDP) which provides rules for maintaining spatial order. The municipality introduced EPPs in October 2019. Zielonki municipality has the fastest growing population density in Krakow agglomeration (based on Local Data Bank Statistics (LDB)) and it is a monofunctional 'bedroom' neighborhood. The strong relationships between Krakow and Zielonki are evinced by a large proportion of pendular migrants learning and working in the city. On the one hand, researched municipality is characterized by a well-developed technical and social infrastructure as well as a highly developed private enterprise sector [75]. On the other hand, Zielonki municipality is characterized by a high proportion of valuable natural areas. Almost $84 \%$ of a studied municipality is located in a conservation area. Almost $22 \%$ of this area belongs to buffer zones of Ojców National Park, 36\% is a Landscape Parks, and the rest $42 \%$ belongs to buffer zones of Landscape Parks (Figure 3).

Using the aggregated indicator of the spatial order of valuable natural areas, each hexagon was evaluated and the ranking of test fields (hexagons) was obtained. The maximum possible score a hexagon could obtain was 15 and the minimum was 0 . None of the hexagons scored maximum, the highest score was 14 and the lowest was 4 . Hexagons were grouped into four types of spatial order-level according to the number of obtained points (based on natural breaks classification): type I: very good (14-11 points), type II: good (9-10 points), type III: mediocre (8-7 points), type IV: low 
(6-4 points). The first type consists of 16 hexagons that were rated the highest. Most hexagons belong to type II (26 hexagons) and type III (21 hexagons). The classification of the hexagons was presented on the map (Figure 4).

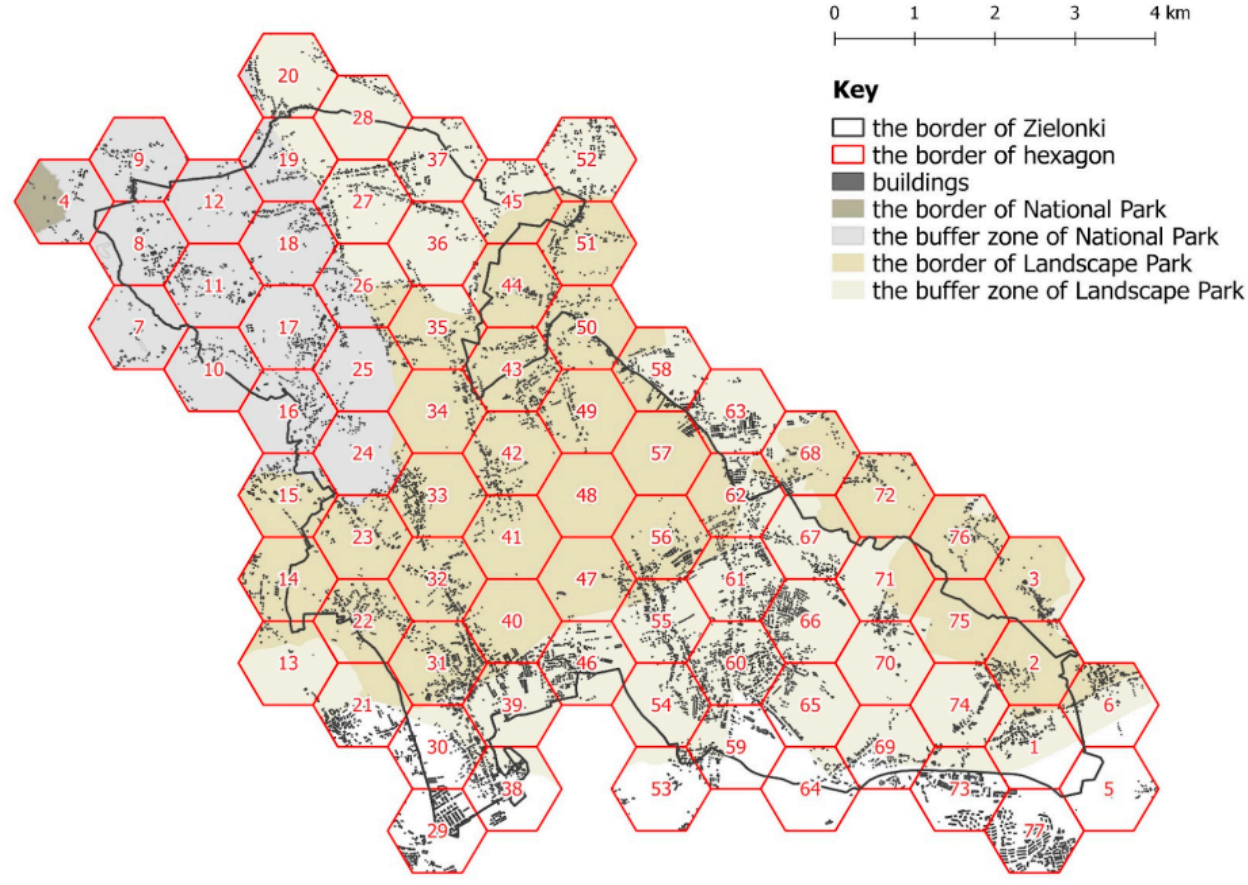

Figure 3. Protected areas, settlement, and borders of test fields in the research municipality- Zielonki.

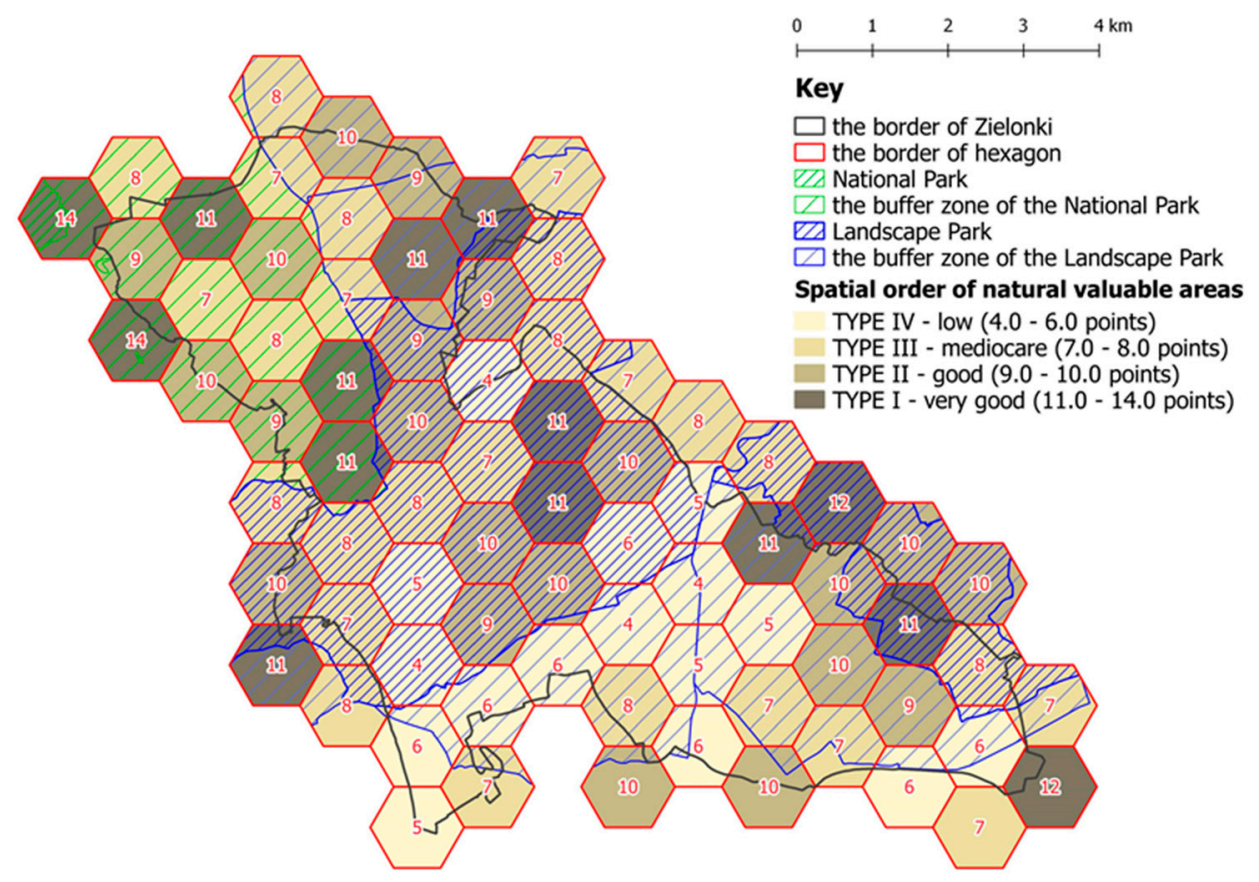

Figure 4. Environmental spatial order of natural valuable areas.

In type I the highest score was obtained for building intensity. All of hexagons have 3 points for that indicator. Almost every hexagon from this group has the highest score for road density and type of building as well. The lowest score in this type was achieved for forestry ratio. Hexagons in type IV were mostly located in the urbanized area. It is an area with high intensity, new ribbon development (Bibice village, Węgrzce village), which gained mostly 0 points for building intensity. The lowest score 
was connected with forestation rate, all test fields had 0 points for that feature. The average total score was 9.8 points for buffer zone of Ojców National Park, 8.4 points for Landscape Protection Parks and 7.2 points for its buffer zones.

\section{Discussion}

Weaknesses in the Polish spatial planning system can be one of the first drawbacks of environmental spatial order. Our results confirm that on average 19\% of main Polish peri-urban areas are covered by Landscape Protection Parks, National Parks and their buffer zones (Natural Reserves mostly overlap with National Parks, Landscape Parks, and their buffer zones). Their protection is executed by LSDPs as well as EPPs but in some cases LSDPs and EPPs are missing. According to Polish Supreme Audit Office [76] this gaps may cause urban sprawl and extensive use of space which in turn diminishes green areas and affect environmental spatial order. Municipalities are aware of that and therefore work on introducing LSDPs. At the same time management bodies of protected areas introduce and execute EPPs. Zielonki is completely covered with LSDP but until recently (October 2019) there was no EPP in force in the municipality. Another important flaw of Polish spatial planning is that neighboring municipalities cannot share the same LSDP. That kind of document can cover only one municipality (or its part). It is common that the provisions of two neighboring LSDPs are not compatible with each other. Therefore, maintaining spatial order in suburban natural valuable areas can be difficult. On the other hand, EPPs are independent of the municipality borders, therefore, they can be a restrictive measure controlling spatial order in the whole protected area. Our method can help to evaluate the efficacy of EPPs, as well as LSDPs and delimit problem areas. As Zielonki introduced new EPPs recently it would be advisable to evaluate the area again to evaluate the results of the provisions of EPPs. Moreover, even though new EPPs should automatically change the provisions of LSPDs, it is rarely the case [77]. The changes resulting from EPPs are introduced into LSPDs when the municipality decides to introduce revisions in LSPDs. Therefore, it would be also advisable to wait until all the changes will be introduced in Zielonki and what is more important will be reflected in the landscape of the municipality.

It is particularly difficult to maintain environmental spatial order in Landscape Parks as the space in Landscape parks can be used for businesses, agriculture, services [58]. EPPs are much less restrictive in Landscape Parks than in National Parks therefore, protection of landscape has to be balanced with economic development and needs of the municipality in Landscape Parks [78]. These areas are abundant in spatial conflicts [79]. Provisions of EPPs are the same for the whole protected area, our method can help to delimit more detailed problem areas inside a protected area. These detailed problem areas could then get special attention in a form of more tailor-made provisions in an LSDP. The method is independent of administrative borders, LSPDs borders, and EPPs. Spatial order should not be bounded by any boundaries. As Foryś claimed [80], lack of continuity of spatial and landscape order as well as uncontrolled directions of the spread of urbanization processes can be results of limiting the research areas to the administrative borders of cities. Therefore, a municipality may not be a proper level for the evaluation of spatial order. We would recommend delimiting research area to problem areas in the researched municipality.

There are two main types of indicators used for spatial order evaluation in the literature. The first type is indicators based on the data obtained from one municipality or from a few municipalities. This is caused by the fact that the most detailed statistical data source is LDB in which there is no data for spatial units smaller than a municipality. Therefore, usually the research on spatial order is made at the scale of municipality (see $[46,81]$ ). The second type of indicator is determined based on small areas, e.g. plots, one street or part of a residential settlement (see $[48,52,82])$. In that type, a direct survey of spatial features may be required as such detailed data are not freely accessible, expensive or they do not exist in official registers. Our method could be useful for municipalities as it would let them avoid a labor-intensive direct survey. 
Our paper indicates that there are substantial differences between spatial order definitions and that no single method of evaluation can address all dimensions of spatial order without important trade-offs. There are currently only a few methods to evaluate spatial order [83]. Mostly, researchers use social, environmental, and economic factors. The choice of factors depends on the aim of the study but in all cases, simplifications are necessary as spatial order is a complex phenomenon. We have also used simplification and chosen to examine only environmental spatial order.

The choice of indicators in the study has been made based on ideas of Śleszyński [84], who proposes 35 indicators for the evaluation of spatial order. Among them, there are nine indicators that are recommended for the evaluation of environmental spatial order. His indicators, however, are theoretical as they are based often on nonexistent data. In many cases, Śleszyński [84] gives a lot of liberty in the choice of various modifications of the indicators but without precise justification for the use of the modification. Our method is based on the existent data, therefore, we had to modify four of Śleszyński's indicators and add one of our own. We adjusted following indicators to existent data: afforestation rate, landscape diversity, density of the total road network, rate of compact development. We added one additional indicator, i.e., building intensity. High building intensity may indicate high antropogenisation of the area and be a sign of possible spatial conflicts in the area of Landscape Park.

In the future, the choice of indicators could be improved as not all possible land cover types were considered. Another indicator showing spatial order could be the presence of lakes and other water bodies. We did not use it in our method as only $1 \%$ of the total surface area of Poland is covered by lakes and rivers [85]. If we were to develop the method for other European countries it could be useful to consider lakes for such countries as Norway or Finland. Poland's coastline is also not very long in comparison to other European countries, only two of municipalities (Kosakowo and Stegna) have coastlines and are in FUA, therefore we did not consider the presence of beaches as an indicator either. However, in the future, this could also be considered as an indicator.

\section{Conclusion}

Our study showed that the level of spatial order and its individual indicators in particular hexagons vary. It proved a difference between the level of spatial order in the buffer zone of Ojcow National Park and in Landscape Parks and their buffer zones.

The conflict between conservation and development must be solved at the proper institutional level. Local authorities should define and protect all valuable natural areas and landscapes, but on the other hand provide some spaces for further development. Our method can be applied at various spatial scales and added as a layer for local spatial planning. Detailed inventories of spatial order components and monitoring of change are necessary in order to obtain reliable data for proper decision-making. Our research can help to identify the weaknesses of the analyzed area, as well as show its highest-rated features, which can help to determine the areas that need improvement or protection. The presented method could serve as a tailor-made tool for environmental management, landscape planning, and nature conservation. The data used for measurement are available for municipalities, which is important strength of presented method. It could help municipalities that struggle with providing their communities with spatial order and that are in the first place not aware what is the condition of municipality's space to reasonably manage their landscapes. The method can be also generalized to more areas both in Poland and in Europe. Our intention was to conduct pilot research on a smaller area, which would then guide larger projects.

We must stress that all the indicators may not give a final answer to the question, what is the condition of spatial order. Taking only one aspect into consideration may cause important omissions. Therefore, the research on spatial order should be further developed.

Author Contributions: Conceptualization, R.R.-C.; methodology, R.R.-C.; formal analysis, R.R.-C., and K.C.; investigation, R.R.-C. and K.C.; writing-original draft preparation, R.R.-C. and B.C.; writing-review and editing, R.R.-C. and B.C.; visualization, K.C. 
Funding: This research was financed by the Ministry of Science and Higher Education of the Republic of Poland, project No DS 3371/KGPiAK/2019.

Conflicts of Interest: The authors declare no conflict of interest.

\section{References}

1. Sanderson, E.W.; Jaiteh, M.; Levy, M.A.; Redford, K.H.; Wannebo, A.V.; Woolmer, G. The Human Footprint and the Last of the Wild. The human footprint is a global map of human influence on the land surface, which suggests that human beings are stewards of nature, whether we like it or not. Bioscience 2006, 52, 891-904. [CrossRef]

2. Ahern, J. Urban landscape sustainability and resilience: The promise and challenges of integrating ecology with urban planning and design. Landsc. Ecol. 2013, 28, 1203-1212. [CrossRef]

3. Merlotto, A.; Piccolo, M.C.; Bertola, G.R. Urban growth and land use/cover change at Necochea and Quequen cities, Buenos Aires province, Argentina. Rev. Geogr. Norte Gd. 2012, 53, 159-176. [CrossRef]

4. Zang, S.; Wu, C.; Liu, H.; Na, X. Impact of urbanization on natural ecosystem service values: A comparative study. Environ. Monit. Assess. 2011, 179, 575-588. [CrossRef]

5. Voghera, A.; La Riccia, L. Ecological Networks in Urban Planning: Between Theoretical Approaches and Operational Measures. In Proceedings of the InInternational Symposium on New Metropolitan Perspectives, Reggio Calabria, Italy, 22-25 May 2018; pp. 672-680.

6. Cheesbrough, A.E.; Garvin, T.; Nykiforuk, C.I.J. Everyday wild: Urban natural areas, health, and well-being. Health Place 2019, 56, 43-52. [CrossRef] [PubMed]

7. Moroni, S.; Minola, L. Unnatural sprawl: Reconsidering public responsibility for suburban development in Italy, and the desirability and possibility of changing the rules of the game. Land Use Policy 2019, 86, 104-112. [CrossRef]

8. Hennig, E.I.; Schwick, C.; Soukup, T.; Orlitová, E.; Kienast, F.; Jaeger, J.A.G. Multi-scale analysis of urban sprawl in Europe: Towards a European de-sprawling strategy. Land Use Policy 2015, 49, 483-498. [CrossRef]

9. Grochowski, M. Metropolizacja a kształtowanie ładu przestrzennego układów zurbanizowanych. Maz. Studia Reg. 2011, 6, 167-172.

10. Kurek, S.; Wójtowicz, M.; Gałka, J. Does suburbanisation contribute to the rejuvenation of a metropolitan area? Changes in the age structure of the Kraków metropolitan area in Poland in the light of recent suburbanisation. Geogr. Pol. 2017, 90, 59-70. [CrossRef]

11. Gałka, J.; Warych-Juras, A. Suburbanization and migration in Polish metropolitan areas during political transition. Acta Geogr. Slov. 2018, 58, 63-72. [CrossRef]

12. Szczepańska, A. Urbanization processes related to the development of residential functions in gminas adjacent to the city of Olsztyn. Bull. Geogr. 2016, 33, 131-143. [CrossRef]

13. European Council of Town Planners (ECTP). The New Charter of Athens; Alinea Editrice: Lisbon, Portugal, 2003.

14. Cieślak, I. Analiza systemu planowania przestrzennego we Francji w nawiązaniu do systemu polskiego. Acta Sci. Pol. Adm. Locorum 2010, 9, 5-16.

15. Pluta, M. Spatial planning in Poland in the context of 'inspire' rules and amendment to the Spatial Planning and Development Act. Geomat. Landmanagement Landsc. 2017, 4, 159-168. [CrossRef]

16. Dutkowski, M. Kulturowe, ideologiczne i społeczne źródła anarchii w gospodarce przestrzennej w Polsce. Studia KPZK 2018, 183, 289-300.

17. Brzeziński, C. System prawny planowania przestrzennego w Polsce i jego konsekwencje przestrzenno-finansowe-Wybrane problemy. Studia Miej. 2016, 23, 53-63.

18. Wdowicka, M.; Mierzejewska, L. Chaos w zagospodarowaniu przestrzennym stref podmiejskich jako efekt braku zintegrowanego systemu planowania (na przykładzie strefy podmiejskieh Poznania). Probl. Rozw. Miast 2012, 9, 40-52.

19. Musiał-Malagó, M. Procesy suburbanizacji obszarów podmiejskich Krakowa. Zesz. Nauk. Unizw. Ekon. Krakowie 2014, 12, 63-77. [CrossRef]

20. Łowicki, D. Land use changes in Poland during transformation. Case study of Wielkopolska region. Landsc. Urban Plan. 2008, 87, 279-288. [CrossRef] 
21. Cegielska, K.; Noszczyk, T.; Kukulska, A.; Szylar, M.; Hernik, J.; Dixon-Gough, R.; Jombach, S.; Valánszki, I.; Filepné Kovács, K. Land use and land cover changes in post-socialist countries: Some observations from Hungary and Poland. Land Use Policy 2018, 78, 1-18. [CrossRef]

22. Barnes, K.; Morgan, J.; Roberge, M.; Lowe, S. Sprawl Development: Its Patterns, Consequences, and Measurement. Technical Report. Available online: https://tigerweb.towson.edu/morgan/files/sprawl_ development.pdf (accessed on 19 November 2019).

23. Kępkowicz, A.; Mantey, D.; Lipińska, H.; Wańkowicz, W. Club Landscape as a Manifestation of Substitutive Public Spaces in Suburbs. Archit. Kraj. 2014, 3, 56-71.

24. Zuziak, Z. Strefa podmiejska w architekturze miasta. In Problem Suburbanizacji. Biblioteka Urbanisty; Lorens, P., Ed.; Urbanista: Warszawa, Poland, 2005; pp. 17-32.

25. Przesmycka, N. Krajobraz kulturowy nowych suburbii Lublina. Teka Kom. Archit. Urban. Studiow Kraj. 2012, VIII/I, 93-103.

26. Solarek, K. Dezurbanizacja południowej strefy podmiejskiej Warszawy. Charakterystyka procesu, główne zagrożenia. In Problem Suburbanizacji. Biblioteka Urbanisty; Lorens, P., Ed.; Urbanista: Warszawa, Poland, 2005; pp. 63-70.

27. Dhanapal, G.; Chaudhry, P. Open Spaces for Urban Sustainability. Available online: Sustainabilityoutlook.in/ content/open-spaces-urban-sustainability (accessed on 20 August 2019).

28. PG-Polish Government. Ustawa z Dnia 27 Marca 2003 r. o Planowaniu i Zagospadowaniu Przestrzennym Dz. U. 2003 Nr 80 poz. 717; PG-Polish Government: Warszawa, Poland, 2003; pp. 1-69.

29. Kołodziejski, J. Kształtowanie ładu przestrzennego metropolii w procesie równoważenia rozwoju polskiej przestrzeni. Od ładu przestrzennego do ładu zintegrowanego. In Kształtowanie ładu Przestrzennego Polskich Metropolii w Procesie Transformacji Ustrojowej III RP; Kołodziejski, J., Parteka, T., Eds.; Biuletyn PAN KPZK: Warszawa, Poland, 2001; pp. 33-76.

30. Kozłowski, L. Kształtowanie ładu przestrzennego jako zadanie badawcze geografii historycznej. Acta Univ. Lodz. Folia Geogr. Socio-Oeconomica 2016, 25, 5-24. [CrossRef]

31. PG-Polish Government. Koncepcja Przestrzennego Zagospodarowania Kraju 2030 Załacznik do Uchwały nr 239 Rady Ministrów z dnia 13 grudnia 2011 r. (poz. 252); PG-Polish Government: Warszawa, Poland, 2011.

32. Skrenty, Ż. Podstawowe zasady planowania przestrzennego-Istota i cele ustanowienia. PWSZ IPiA Studia Lubus. 2010, 7, 245-260.

33. Tebernacka, M. Konflikty dotyczace interpretacji pojeccia "ład przestrzenny” w planowaniu i zagospodarowaniu przestrzennym. In Płaszczyzny Konfliktów w Administracji Publicznej; Tebernacka, M., Raszewska-Skałecka, R., Eds.; Wolters Kluwer: Warszawa, Poland, 2010; pp. 404-414.

34. Mierzejewska, L. Rozwój zrównoważony, jako kategoria ładu przestrzennego. In Społeczno-Gospodarcze $i$ Przyrodnicze Aspekty Ładu Przestrzennego; Ślęzak, T., Zioło, Z., Eds.; Biuletyn PAN KPZK: Warszawa, Poland, 2003; pp. 127-140.

35. Woźniak, M. Ład przestrzenny jako paradygmat zrównoważonego gospodarowania przestrzenią. Białostockie Studia Prawnicze 2015, 18, 167-182.

36. Mikołajczyk, M.; Raszka, B. Multidimensional Comparative Analysis as a Tool of Spatial Order Evaluation: A Case Study from Southwestern Poland. Pol. J. Environ. Stud. 2019, 28, 3287-3297. [CrossRef]

37. Balon, J. Spatial Order in the Natural Environment of the Polish Tatra Mts. Pr. Geogr. IGiGP UJ 2005, 115, 19-29.

38. Szolginia, W. Ład Przestrzenny w Zespole Mieszkaniowym; Instytut Gospodarki Przestrzennej i Komunalnej: Urbanista: Warszawa, Poland, 1987; ISBN 83-85002-23-5.

39. Markowski, T. Społeczno-gospodarcze i przyrodnicze aspekty ładu przestrzennego. In Biuletyn KPZK PAN; Zioło, Z., Ślęzak, T., Eds.; Urbanista: Warszawa, Poland, 2003.

40. Fogel, P. Wspomaganie procesu tworzenia polityki przestrzennej w gminie poprzez wykorzystanie prostych analiz GIS. Folia Geogr. Socio-Oeconomica 2013, 14, 45-58.

41. Szczepański, P.; Zbierska, A.; Zydroń, A. Analiza porównawcza wskaźników ładu przestrzennego na poziomie gminy. Studia i Prace Wydziału Nauk Ekon. i Zarzadzania 2015, 40, 189-200.

42. Falkowski, J. Ład i nieład przestrzenny w metodyce zrównoważonego rozwoju społeczno- gospodarczego (na przykładzie województwa kujawsko-pomorskiego). Rozw. Reg. Polityka Reg. 2017, 38, 195-215.

43. Majorek, A. Wpływ ładu przestrzennego na jakość życia mieszkańców na przykładzie Józefosławia w gminie Piaseczno. Acta Sci. Pol. Adm. Locorum 2018, 16, 197-206. [CrossRef] 
44. Gorzelak, G. Szkic o wymiarach ładu przestrzennego. In Społeczno-Gospodarcze i Przyrodnicze Aspekty Ładu Przestrzennego; Ślęzak, T., Zioło, Z., Eds.; Biuletyn PAN KPZK: Warszawa, Poland, 2003; pp. 55-69.

45. Szczepańska, A.; Pietrzyk, K. A multidimensional analysis of spatial order in public spaces: A case study of the town Morag, Poland. Bull. Geogr. Socio Econ. Ser. 2019, 44, 115-129. [CrossRef]

46. Mikołajczyk, M.; Raszka, B. Indicators of the environmental aspect of spatial order as a tool for the environmental protection in suburban areas. Geomat. Landmanag. Landsc. 2016, 3, 105-114. [CrossRef]

47. Kopeć, A. Poziom ładu przestrzennego w podmiejskiej strefie aglomeracji Trójmiasta. Kategoria społeczna i legislacyjna. In Gospodarka Przestrzenna Społeczeństwu; Ratajczak, W., Stachowiak, K., Eds.; Bogucki Wydawnictwo Naukowe: Poznań, Poland, 2010; pp. 123-143.

48. Różycka-Czas, R.; Salata, T.; Gawroński, K.; Czesak, B.; Cegielska, K. Wykorzystanie Systemu Informacji Przestrzennej do oceny stanu ładu przestrzennego. Acta Sci. Pol. Form. Circumiectus 2016, 15, 73-84. [CrossRef]

49. Parysek, J. Ład przestrzenny jako kategoria pojęciowa i planistyczna. In Społeczno-Gospodarcze i Przyrodnicze Aspekty Ładu Przestrzennego; Ślęzak, T., Zioło, Z., Eds.; Biuletyn KPZK PAN: Warszawa, Poland, 2003; pp. 111-126.

50. Podciborski, T.; Dąb, A. Ocena zabudowy zagrodowej w aspekcie ładu przestrzennego. Acta Sci. Pol. Adm. Locorum 2013, 12, 49-57.

51. Podawca, K.; Pawłat-Zawrzykraj, A. Ocena kształtowania lokalnego ładu przestrzennego zabudowy jednorodzinnej w gminie miejsko-wiejskiej Kałuszyn. Probl. Rozw. Miast 2013, 12/1, 21-29.

52. Podciborski, T.; Kil, J. Ład przestrzenny obszarów peryferyjnych w aspekcie podziałów nieruchomości niezurbanizowanych. Barom. Reg. 2011, 3, 79-84.

53. Galiński, M.; Siwek, G.J. Szuwarski J. Metoda bonitacji punktowej jako narzędzie waloryzacji zjawisk przestrzennych (Point grading method as spatial phenomena valorization tool). In Geomatyka i Inżynieria. Kwart. Nauk. Państwowej Wyższej Szk. Tech.-Ekonom; Wyższa Szk. Tech. w: Jarosłąwiu, Jarosław, 2013; Volume 2, pp. 5-20.

54. Śleszyński, P.; Deręgowska, A.; Kubiak, Ł.; Sudra, P.; Zielińska, B. Analiza Stanu i Uwarunkowań Prac Planistycznych w Gminach w 2017 roku. Available online: https:/www.igipz.pan.pl/aktualnosc/items/ analiza-stanu-2017.html (accessed on 19 November 2019).

55. Polski, J. Systemowe planowanie przestrzenne a ochrona środowiska. Czas. Tech. Archit. 2007, 104, 73-78.

56. Feltynowski, M. Planowanie miejscowe a użytkowanie terenów w wybranych gminach wiejskich województwa łódzkiego. Studia Obszarów Wiejskich 2013, 34, 221-231.

57. Korbel, W. Skuteczność strategicznego planowania przestrzennego gmin w kontekście istniejącego i projektowanego w Polsce prawa planowania przestrzennego. Zesz. Nauk. Politech. Częstochowskiej 2015, 20, 36-57.

58. PG-Polish Government. Ustawa z dnia 16 kwietnia 2004 r. o ochronie przyrody. Dz.U. 2004 nr 92 poz. 880; PG-Polish Government: Warszawa, Poland, 2004.

59. Wrana, K. Naprzeciw oczekiwaniom społeczności lokalnej. Ekoprofit 2000, 9, 50-52.

60. Statistics Poland. Area and Population in the Territorial Prole in 2019; Statistics Poland: Warsaw, Poland, 2019. (In Polish)

61. Dijkstra, L.; Poelman, H.; Veneri, P. The EU-OECD Definition of a Functional Urban Area. European Commission, Department for Regional and Urban Policy. Available online: https://www.oecd.org/cfe/regional-policy/THE\% 20EU-OOECD\%20DEFINITION\%20OF\%20A\%20FUNCTIONAL\%20URBAN\%20AREA.pdf (accessed on 19 November 2019).

62. Bartkowski, T. Zastosowania Geografii Fizycznej; PWN: Warszawa, Poland, 1986.

63. Bastian, O.; View, E. Analyse und Ökologische Bewertung der Landschaft; Spektrum Akademischer Verlag: Heidelberg, Germany, 1999.

64. PG-Polish Government. Rozporzadzenie Ministra Spraw Wewnętrznych i Administracji z dnia 17 listopada 2011 r. w Sprawie Bazy Danych Obiektów Topograficznych Oraz Bazy Danych Obiektów Ogólnogeograficznych, a Także Standardowych Opracowań. Dz.U. 2011 nr 279 poz. 1642 kartograficz; PG-Polish Government: Warszawa, Poland, 2011.

65. Carrus, G.; Scopelliti, M.; Lafortezza, R.; Colangelo, G.; Ferrini, F.; Salbitano, F.; Agrimi, M.; Portoghesi, L.; Semenzato, P.; Sanesi, G. Go greener, feel better? The positive effects of biodiversity on the well-being of individuals visiting urban and peri-urban green areas. Landsc. Urban Plan. 2015, 134, 221-228. [CrossRef] 
66. Oh, B.; Lee, K.J.; Zaslawski, C.; Yeung, A.; Rosenthal, D.; Larkey, L.; Back, M. Health and well-being benefits of spending time in forests: Systematic review. Environ. Health Prev. Med. 2017, 22, 71. [CrossRef] [PubMed]

67. Kaliszewski, A.; Wysocka-Fijorek, E.; Jabłoński, M.; Młynarski, W. Aktualizacja Krajowego Programu Zwiększania Lesistości 2014 Synteza; IBL: Sękocin Stary, Poland, 2014.

68. Palmieri, A.A.; Dominici, P.; Kasanko, M.; Martino, L. General and Regional Statistics. Diversified Landscape Structure in the EU Member; Eurostat: Brussels, Belgium, 2011; Volume 21.

69. Sallay, A.; Jombach, S.; Filepné Kovács, K. Landscape changes and function lost landscape values. Appl. Ecol. Environ. Res. 2012, 10, 157-172. [CrossRef]

70. Świdyński, J. Obszary przyrodniczo cenne w procesach racjonalnego planowania przestrzeni zurbanizowanej. In Wspótczesne Uwarunkowania Gospodarowania Przestrzenia- Szanse i Zagrożenia dla Zrównoważonego Rozwoju. Planowanie Przestrzenne; Maciejewska, A., Ed.; Oficyna Wydawnicza PW: Warszawa, Poland, 2014; p. 163.

71. PG-Polish Government. Ustawa z Dnia 3 lutego 1995 r. o Ochronie gruntów Rolnych i Leśnych; PG-Polish Government: Warszawa, Poland, 1995; p. 23.

72. Mayhew, S. A Dictionary of Geography; Oxford Univ. Press: Oxford, UK; New York, NY, USA, 1997.

73. Jenks, G. The Data Model Concept in Statistical Mapping. Int. Yearb. Cartogr. 1967, 7, 186-190.

74. Sejmik Województwa Małopolskiego. Uchwała Nr XLVII/732/18 Sejmiku Województwa Małopolskieg o z dnia 26 marca 2018 r. w sprawie zmiany Uchwały Nr XV/174/03 Sejmiku Województwa Małopolskiego z dnia 22 grudnia 2003 roku w sprawie uchwalenia Planu Zagospodarowania Przestrzennego Województwa Małopolskiego; Regional Council of the Małopolska Region: Kraków, Poland, 2018.

75. Bieda, A.; Jasińska, E. Analiza rynku nieruchomości na byłych obszarach wiejskich na przykładzie aglomeracji krakowskiej. Infrastrukt. i Ekol. Teren. Wiej. 2010, 12, 5-15.

76. NIK System gospodarowania przestrzenia gminy jako dobrem publicznym. Informacja o wynikach kontroli (eng. Information on the results of the inspection, Municipal spatial economy as a public good). 2017. Available online: https://www.nik.gov.pl/plik/id,13209,vp,15626.pdf (accesed on 19 November 2019).

77. Szulczewska, B. Koncepcja planu ochrony a planowanie przestrzenne gmin i regionów. Studia i Mater. Cent. Edukac. Przyr. Leśnej 2008, 3, 240-251.

78. Mastalska-Cetera, B.; Krajewski, P. Plany ochrony parku krajobrazowego jako narzędzie wspomagające zrównoważony rozwój (eng. Protection plans of landscape park as a tool supporting sustainable development). Probl. Ekol. Kraj. 2014, 37, 147-155.

79. Krajewski, P. Problemy planistyczne na terenach parków krajobrazowych w sasiedztwie Wrocławia na przykładzie Ślężańskiego Parku Krajobrazowego. In Prace Naukowe Uniwersytetu Ekonomicznego we Wrocławiu. Gospodarka Przestrzenna. Aktualne Aspekty Polityki Społeczno-Gospodarczej i Przestrzennej; Potocki, J., Ładysz, J., Eds.; Wyd. Uniwersytetu Ekonomicznego we Wrocławiu: Wrocław, Poland, 2014; pp. 147-154.

80. Foryś, I. Wybrane społeczno-ekonomiczne aspekty planowania przestrzennego w procesie gospodarowania przestrzenią. Biul. KPZK PAN 2015, 257-258, 193-206.

81. Śleszyński, P. Propozycja kompleksowej koncepcji wskaźników zagospodarowania i ładu przestrzennego. In Wskaźniki Zagospodarowania i Ładu Przestrzennego w Gminach; Biuletyn PAN KPZK: Warszawa, Poland, 2013; Volume 252, pp. 176-231.

82. Cymerman, R.; Podciborski, T. Propozycja metody oceny ładu przestrzennego przy analizie stanu zagospodarowania obszarów wiejskich. Acta Sci. Pol. Adm. Locorum 2004, 1, 31-43.

83. Warczewska, B. Analiza zapisów dotyczących ładu przestrzennego w miejscowych planach zagospodarowania przestrzennego gminy Siechnice. Archit. Kraj. 2014, 4, 72-79.

84. Śleszyński, P. Weryfikacja $i$ Testowanie Wskaźników Zagospodarowania $i$ Ładu Przestrzennego w Gminach; IGIPZ PAN: Warszawa, Poland, 2013.

85. EEA (European Environmental Agency) Delineation of Water Bodies. Available online: https://www.eea.europa.eu/themes/water/european-waters/water-quality-and-water-assessment/ water-assessments/delineation-of-water-bodies\#tab-based-on-data (accessed on 6 November 2019).

(C) 2019 by the authors. Licensee MDPI, Basel, Switzerland. This article is an open access article distributed under the terms and conditions of the Creative Commons Attribution (CC BY) license (http://creativecommons.org/licenses/by/4.0/). 